\title{
Peran Kepala Sekolah dalam Pengembangan Karakter Siswa Berbasis Profesionalisme Guru
}

\author{
Ahmad Mushthofa \\ UIN Sunan Kalijaga Yogyakarta \\ ahmadmushthofao2@gmail.com \\ Muhammad Amin Khizbullah \\ UIN Sunan Kalijaga Yogyakarta \\ aminkhiz27@gmail.com \\ Reza Aditya Ramadhani \\ UIN Sunan Kalijaga Yogyakarta \\ ramadhanirezao21@gmail.com
}

DOI: https://doi.org/10.21154/sajiem.v3i1.81

\begin{abstract}
Education is not only focused on the intellectual factors that a person has while studying but also must be integrated with other factors such as attitudes, behavior, and character. With this, the article describes the role of the principal at SMK Cendekia Madiun in developing professional teachers in the educational process who can improve student character. The data collection technique used is interviews. Data processing and analysis techniques through data reduction, data presentation, and drawing conclusions. The role of school principals in improving teacher professionalism at Cendekia Vocational Schools by empowering teachers is manifested in IHT (in House Training) activities, KKG (Teacher Working Group) or MGMP (Subject Teacher Consultations) activities and directing teachers to set good examples, provide guidance, direction, holding character development, extra-curricular and religious activities. As well as creating new activities in the form of planting vegetables and raising catfish which are divided into each class. In addition, SMK Cendekia Madiun holds character development activities that instill the character of students who are honest, disciplined, independent, creative, love the homeland, democratic attitude, hard work, love to read, care for the environment, social care, religious, sense of responsibility, and especially according to the school's vision and mission that can develop students who are skilled, competitive, have faith and fear God Almighty.
\end{abstract}

Keywords: Principal, Student Character, Teacher Professionalism. 


\section{Pendahuluan}

Realitas tindak kekerasan dalam praktik pendidikan Indonesia menjadi bukti bahwa pendidikan karakter belum terimplementasi dengan baik. Demikian pula berbagai perilaku menyimpang yang dilakukan oleh pengelola, pengurus, maupun pesrta didik misalnya ketidak jujuran dalam pendidikan seperti kasus bertindak curang berupa tindakan menyontek pekerjaan teman atau mencontoh buku pelajaran ketika ujian seolah-olah kebiasaan seharihari ${ }^{1}$. Oleh sebab itu, mempersiapkan guru berkualitas menjadi perhatian dunia global saat ini, dikarenakan paradigma dunia yang memandang pendidikan sebagai sentral pokok dalam melakukan perbaikan pada penyakit sosial masyarakat sekaligus sebagai instrumen kunci dalam memajukan dan membangun suatu bangsa ${ }^{23}$. Dengan demikian, guru diharapkan mampu berpartisipasi dalam pembangunan karakter nasional untuk mewujudkan insan yang bertakwa kepada Tuhan Yang Maha Esa, unggul ilmu pengetahuan dan teknologi, memiliki jiwa estetis, etis, berbudi pekerti luhur, dan berkepribadian ${ }^{4}$.

Persoalan tenaga ahli atau profesionalisme guru dalam pendidikan bukanlah persoalan kecil, tetapi merupakan permasalahan besar yang memerlukan pemecahan. Pendidikan dapat mencapai tujuannya, jika pelaksana pendidikannya merupakan seorang yang ahli dalam bidangnya 5. Dalam pendidikan kepala sekolah harus mampu menimbulkan dan menggerakkan semangat guru, staf, dan siswa dalam mencapai tujuan pendidikan yang telah ditetapkan ${ }^{6}$. Dengan hal inilah Kepala sekolah harus memiliki karakter yang menunjukkan integritasnya. Segala bentuk kegiatan sekolah selalu diarahkan pada peningkatan profesionalisme tenaga pendidik dan kependidikan ${ }^{7}$. Sebagai kegiatan yang berkaitan dengan pembinaan potensi anak yang sedang mengalami perkembangan, maka seorang guru harus benar-benar ahli dalam tugasnya ${ }^{8}$. Guru juga harus mampu memantau perkembangan cara berfikir, tindakan dan perilaku para siswa di sekolah, keluarga, dan masyarakat ${ }^{9}$.

Tulisan ini secara khusus menunjukkan pengembangan profesionalisme guru tidak hanya pelatihan, dan seminar saja tetapi kepala sekolah juga memberi arahan, motivasi kepada guru dalam melaksanakan kegiatan maupun pembelajaran agar guru semangat dalam melaksanakan tugasnya, Guru yang professional, guru yang selalu mengikuti dan melaksanakan tugasnya dengan baik sesuai arahan kepala sekolah, Karena kepala sekolah SMK Cendekia juga di tuntut untuk menciptakan peserta didik yang berkarakter sesuai dengan visi dan misi sekolah yaitu menciptakan peserta didik yang terampil, kompetitif, beriman dan bertakwa kepada Tuhan YME. Dengan ini, tulisan ini bertujuan untuk menguji bahwa dibalik pengembang profesional guru banyak manfaat bagi peningkatan karakter peserta didik sesuai dengan kebutuhan dan perkembangan zaman. Oleh sebeb itu, dalam pendidikan guru juga di tuntut harus menyiapkan peserta didik menjadi manusia seutuhnya yang berbudi pekerti

\footnotetext{
${ }^{1}$ Hendro Widodo \& Etyk Nurhayati, Manajemen Pendidikan Sekolah Madrasah dan Pesantren, ed. oleh Nur Asri (Bandung: PT Remaja Rosdakarya, 2020)

2 Baharuddin \& Rabial Kanada, "Pengembanganprofesionalisme Guru Melalui In House Training," Journal of Islamic Education Management, 3.2, (2017), 1-20

${ }^{3}$ Nyimas Atika, "Pengaruh Manajemen Pendidikan Budaya dan Karakter Pendidikan Di Sekolah Dasar Negeri 114 Palembang,” El-Idare: Jurnal Manajemen Pendidikan Islam, 3.1 (2017), 95-111.

4 Fatkuroji, "Kesiapan Pendidik Dan Tenaga Kependidikan Dalam Menyonsong Masyarakat Ekonomi Asean,” Jurnal Idaroh, 1.1 (2015), 101-14

5 Suriadi, "Profesionalisme Guru dalam Perspektif Al-Qur'an," Lentera Pendidikan, 21.1 (2017), 123.

${ }^{6}$ Hendro Widodo \& Etyk Nurhayati.

${ }^{7}$ Nuzuar \& Idi Warsah Ahmad Syukri, "Peran Kepala Madrasah Dalam Meningkatkan Etos Kerja Guru," 23.3 (2019), 2019.

8 Halid Hanafi. La Adu \& H Muzakkir, Profesionalisme Guru Dalam Pengelolaan Kegiatan Pembelajaran di Sekolah, ed. oleh Haris Ari Susanto (Yogyakarta: CV Budi Utama, 2018).

${ }^{9}$ Dede Rosyada, Madrasah dan Profesionalisme Guru, ed. oleh Zaenal Muttaqin \& Luthfy Rijalul Murodi, Cetakan ke (Jakarta: KENCANA, 2017).
} 
luhur ${ }^{10}$. Dengan demikian salah satu faktor yang menjadi ukuran keberhasilan proses pembelajaran adalah kinerja tenaga kependidikan" .

Dalam kaitannya dengan kegiatan pendidikan unsur yang sangat penting menentukan ketercapaian tujuan adalah sumberdaya guru ${ }^{12}$. Pengakuan guru sebagai tenaga profesional semakin nyata. Pengakuan atas kedudukan guru sebagai tenaga profesional berfungsi mengangkat martabat dan peran guru sebagai agen pembelajaran untuk meningkatkan mutu pendidikan nasional ${ }^{13}$. Oleh sebab itu, SMK Cendekia kepala sekolah selalu mengutamakan kualitas pendidikan dengan menciptakan guru yang professional yang dapat mengajar sesuai standar kementrian pendidikan dengan mengacu pada visi, misi, tujuan pendidikan disekolah. Permasalahan diungkap oleh peneliti yaitu bagaimana peran kepala sekolah mengembangkan profesional guru selama ini, Seiring kemajuan ilmu pengetahuan dan teknologi yang semakin berkembang, sedangkan setiap guru memiliki kemampuan dan karakter yang berbeda. Oleh karena itu, dengan pengembangan profesi guru dalam proses pendidikan dapat meningkatkan karakter peserta didik.

\section{Metode Penelitian}

Dalam penelitian yang berlokasi di SMK Cendekia Madiun yang terletak di Jl. Letkol Suwarno Kanigoro Katoharjo Kota Madiun Provinsi Jawa Timur, dengan subjek penelitian adalah guru dan kepala sekolah. Peneliti menggunakan metode pendekatan kualitatif deskriptif. Sekolah ini sebagai sebuah lembaga pendidikan setingkat menengah atas yang bercirikan pendidikan kejuruan berkarakter, dengan peranan kepala sekolah, dalam mengembangkan profesionalisme guru untuk meningkatkan karakter peserta didik di SMK Cendekia Madiun. Dalam penelitian ini, sumber data primer dari penelitian ini adalah berasal dari wawancara dengan pihak-pihak terkait seperti kepala sekolah dan dewan guru SMK Cendekia Madiun.

Penelitian menggunakan pendekatan penelitian lapangan kualitatif dimana untuk memperoleh data yang akurat, maka penulis datang ke narasumber maupun dilaksanakan secara online. Sedangkan data sekunder ialah sumber yang mendukung serta hubungan penelitian yang dibahas dimana sumber data sekunder dalam penelitian ini di antaranya bersumber dari buku-buku, dokumentasi, dan kepustakaan serta sumber-sumber lainnya yang mendukung dan berkaitan dengan masalah dalam penelitian tersebut.

Pemilihan informan dilakukan dengan cara dua guru dipilih untuk diwawancarai secara mendalam. Pemilihan guru untuk memperhatikan pelaksanaan peningkatan profesi maupun karakter peserta didik. Kepala sekolah dipilih dengan memperhatikan proses perencanaam, pelaksanaan maupun evaluasi yang dilakukan. Sekolah dipilih dengan memperhitungkan dan memperhatikan kategori pengembangan profesionalisme guru yang memiliki relevansi terhadap kualitas pembelajaran di suatu lembaga pendidikan.

Teknik analisa data; 1) reduksi data, dalam penelitian ini data yang diperoleh dari informan kunci, yaitu Kepala sekolah, waka Kurikulum, dan Guru, disusun secara sistematis agar memperoleh gambaran yang sesuai dengan tujuan penelitian. Begitu pula data yang diperoleh dari informan pelengkap disusun secara sistematis agar memperoleh gambaran yang sesuai dengan tujuan penelitian, 2) penyajian data, data yang sudah direduksi dan diklasifikasikan berdasarkan kelompok masalah yang diteliti, sehingga memungkinkan adanya

${ }^{10}$ Baharuddin, "Pembentukan Karakter Siswa dan Profesionalisme Guru Melalui Budaya Literasi Sekolah,” El-Idare: Jurnal Manajemen Pendidikan Islam, 3.1 (2017), 21-40.

${ }^{11}$ Moh.Syamsudduha \& St.Wayong Bardin, "Hubungan Kinerja Pendidik dan Tenaga Kependidikan dengan Keberhasilan Proses Pembelajaran," Journal of Chemical Information and Modeling, 5.2 (2019), 81-92.

${ }^{12}$ Susdiyanto. Ilmi Sawianti, Musdalifah, "Pengaruh Iklim Sekolah Terhadap Kinerja Guru di SMP Negeri 1 Ulaweng Kabupaten Bone," Journal of Islamic Education Management, 5.1 (2019), 22-30.

${ }^{13}$ Febriyanti, "Kualitas Madrasah Dan Profesionalisme Guru (Undang-Undang 14 Tahun 2005)," El-Idare: Jurnal Manajemen Pendidikan Islam, 2.2 (2016), 31-51. 
penarikan kesimpulan atau verifikasi, 3) verifikasi, peneliti pada tahap ini mencoba menarik simpulan berdasarkan tema untuk menemukan makna dari data yang dikumpulkan. ${ }^{14}$

Setelah seluruh data dan informasi terkumpul, maka langkah selanjutnya adalah pengolahan dan analisa data. Tinjauan data atau bisa disebut analisis data kualitatif adalah metode di mana data dari wawancara, laporan lapangan dan sumber daya lainnya diidentifikasi dan disusun secara sistematis, sehingga dapat dengan mudah dipahami dan hasilnya dikomunikasikan dengan orang lain. Analisis data dilakukan dengan mengorganisasikan sebuah data, pembagian dalam satuan, sintesis, desain, pemilihan apa yang signifikan dan apa yang akan dipelajari dan kesimpulan yang dibagikan kepada orang lain. ${ }^{15}$

\section{Temuan dan Pembahasan}

Pendidikan merupakan sumber daya utama bagi kemajuan suatu bangsa ${ }^{16}$. Keberhasilan pendidikan di sekolah sangat ditentukan oleh keberhasilan kepala sekolah dalam mengelola tenaga kependidikan yang tersedia di sekolah. Kepala sekolah merupakan salah satu komponen pendidikan yang berpengaruh dalam meningkatkan kinerja guru ${ }^{17}$. Dalam pelaksanaannya, proses pembelajaran merupakan komponen pendidikan yang selalu melibatkan peserta didik dan guru ${ }^{18}$ Kinerja guru merupakan perwujudan kemampuan dan keterampilan berdasarkan kewenangan yang dimilki dalam tugas pokoknya, yaitu keterampilan mengajar. ${ }^{19}$. Kegiatan pedidikan di sekolah dilaksanakan dalam rangka mewujudkan tujuannya yaitu kegiatan pembelajaran itu sendiri ${ }^{20}$. Oleh sebab itu, seorang guru dapat melaksanakan tugasnya secara profesional dalam kegiatan pembelajaran sangat memerlukan wawasan yang mantap dan utuh ${ }^{21}$.

Peran kepala sekolah sebagai pemimpin mencerminkan tanggung jawab untuk menggerakan seluruh sumber daya di sekolah, sehingga lahir etos kerja dan produktivitas yang tinggi mencapai tujuan ${ }^{22}$. Kepala sekolah tidak hanya bertanggung jawab atas kelancaran jalannya sekolah secara akademis saja, akan tetapi seluruh kegiatan, keadaan lingkungan sekolah, kondisi dan situasinya, serta hubungan masyarakat merupakan tanggung jawabnya ${ }^{23}$. Kepala sekolah merupakan kunci keberhasilan dalam mengelola sekolah. Kemampuan kepala sekolah untuk menimbulkan kemampuan yang kuat dengan penuh semangat dan percaya diri bawahan dalam menjalankan tugas, serta memberi bimbingan dan arahkan pada bawahan,

\footnotetext{
${ }^{14}$ Sugiyono, Metode Penelitian Pendidikan (Pendidikan Kuantitatif, Kualitatif, dan RED), 320.

${ }^{15}$ Ibid, 337.

${ }^{16}$ Euis Karwati \& Donni Juni Priansa, Kinerja dan Profesionalisme Kepala Sekolah Membangun Sekolah yang Bermutu, ed. oleh Sumartini (Bandung: Alfabeta,cv, 2013) <https://doi.org/Pdk101(xiv+290)16x24cm>.

${ }^{17}$ Hendro Widodo \& Etyk Nurhayati.

${ }^{18}$ Muh. Khalifah Mustami Akmal Rajab, Muhammad Ramli, "Pengaruh Kualitas Layanan dan Kompetensi Profesional Guru terhadap Prestasi Belajar Peserta Didik," Journal of Islamic Education Management, 5.2 (2019), 39-52 <https://doi.org/10.1128/AAC.03728-14>.

${ }^{19}$ Murtiningsih Murtiningsih dan Bukman Lian, "Proses Pengambilan Keputusan Kepala Sekolah Terhadap Peningkatan Kinerja Guru Smp," JMKSP (Jurnal Manajemen, Kepemimpinan, dan Supervisi Pendidikan), 2.1 (2017), 87-96 <https://doi.org/10.31851/jmksp.v2i1.1156>.

20 Febriyanti, "Peran Kepala Sekolah Sebagai Supervisor Dalam Meningkatkan Kualitas Pembelajaran di MA Patra Mandiri Plaju Palembang," jurnal of Islamic Education Management, 3.1 (2017), 58-75.

${ }^{21}$ Arifuddin Siraj \& Andi Maulana. Nur Rahmi, "Profesionalisme Guru Madrasah Ibtidaiyah Melalui Kelompok Kerja Guru (KKG) di Kecamatan Gantarang Kabupaten Bulukumba,” Journal of Islamic Education Management, 5.2 (2019), 1-10.

${ }^{22}$ Haryo Franky Souisa, “Analisis Peran Kepala Sekolah Dalam Meningkatkan Profesionalisme Guru Sd Inpres 18 Kabupaten Sorong ( Leadership ),” Journal Soscied, 1.2 (2018).

${ }^{23}$ Astuti dan Danial, "Kepemimpinan Kepala Madrasah dalam Membangun Budaya Madrasah Yang Kondusif di Madrasah Aliyah Negeri," Journal Of Islamic Education Management, 5.1 (2019), 31-45.
} 
memberikan dorongan, memacu dan berdiri di depan demi kemajuan dan memberikan inspirasi untuk mencapai tujuan ${ }^{24}$. Peran dan tugas kepala sekolah sebagai manajer dapat dilihat dari kemampuan kepala sekolah dalam menyusun progam disekolah, organisasi kepegawaian yang tepat, menggerakkan staf, dan mengoptimalkan semua sumber daya sekolahan ${ }^{25}$.

Guru sebagai salah satu steakholder penting dalam pembelajaran juga tidak luput dari problem-problem mengajar, karenanya dibutuhkan pengalaman, masukan, bantuan ${ }^{26}$. Seorang guru harus giat meningkatkan kemampuannya baik kemampuannya sebagai pengajar yang mengajarkan suatu bidang ilmu maupun kemampuannya sebagai pendidik ${ }^{27}$. Guru berperan sebagai pengajar yang tugasnya mencerdaskan bangsa. Guru juga berfungsi sebagai motivator, fasilitator, dan evaluator. Guru yang profesional merupakan factor penentu proses pendidikan yang berkualitas ${ }^{28}$. Betapa bagusnya sebuah kurikulun (official), hasilnya sangat bergantung pada apa yang dilakukan guru di luar maupun di dalam kelas $(\text { actual })^{29}$. Hal tersebut menunjukkan bahwa kinerja guru di sekolah mempunyai peran penting dalam pencapaian tujuan sekolah ${ }^{30}$.

Pada hakekatnya kinerja guru adalah perilaku yang dihasilkan guru dalam melaksanakan tugasnya dan mengajar di kelas sesuai dengan kriteria yang sudah ditetapkan sehingga menjadi guru profesionalisme, sedangkan guru profesional adalah guru yang berkualitas, berkompeten, dan guru yang dikehendaki untuk mendatangkan prestasi belajar serta mampu mempengaruhi proses belajar siswa yang dapat menghasilkan prestasi belajar siswa yang lebih baik ${ }^{31}$. Oleh sebab itu guru yang profesional diharapkan memiliki kinerja yang tinggi yang dapat memuaskan semua pihak yang berkepentingan (stakeholders), yaitu peserta didik, orang tua, dan masyarakat dalam arti luas. Di samping memuaskan stakeholders, kinerja yang tinggi juga memuaskan diri sendiri. Bagi seorang profesional, kepuasan rohani merupakan kompensasi utama yang diharapkan dari pekerjaan, sedangkan kepuasan material merupakan hal yang sekunder. ${ }^{32}$.

Pendidikan merupakan pilar tegaknya suatu bangsa. Melalui pendidikan bangsa akan tegak mampu menjaga martabat. Dalam era ini, pendidikan bukan hanya terpaku dalam faktor intelektual yang dimiliki sesorang saat menempuh pendidikan namun juga harus diintegrasikan dengan faktor lain seperti halnya sikap, perilaku, dan karakter ${ }^{33}$. Karakter menurut Bahasa Depdiknas adalah "bawaan, hati, jiwa, kepribadian, budi poekerti, perilaku,

24 Sitti Mania Ike Yuniarty, Muhammad Ramli, "Pengaruh Gaya Kepemimpinan Kepala Madrasah terhadap Kedisiplinan Guru pada Madrasah Ibtidaiyah di Kabupaten Bulukumba,” Journal of Islamic Education Management, 4.2 (2018), 182-95.

${ }^{25}$ Euis Karwati \& Donni Juni Priansa.

${ }^{26}$ Andi M. Darlis, "Pelaksanaan Supervisi Akademik Guru Pendidikan Agama Islam oleh Kepala Madrasah Aliyah Negeri di Provinsi Kepulauan Bangka Belitung," Journal of Islamic Education Management, 6.1 (2020), 63-72.

${ }^{27}$ Abdul Aziz Saefudin Siska Candra Ningsih, Titis Sunanti, Padrul Jana, Gunawan, Christina Eva Nuryani, "Professionalism Development Of Sdn Tamansari I Yogyakarta' S Teachers Through Class Action," Jurnal Berdaya Mandiri, 2.1 (2020), 215-24.

${ }_{28}$ Sholihat Seftiani, Afridha Sesrita, dan Irman Suherman, "Pengaruh Profesionalisme Guru Terhadap Motivasi Belajar Siswa SD Negeri,” SITTAH: Journal of Primary Education, 1.2 (2020), 125-38 $<$ https://doi.org/10.30762/sittah.v1i2.2486>.

${ }^{29}$ Haryo Franky Souisa.

${ }^{30}$ Murtiningsih dan Lian.

${ }^{31}$ Murtiningsih dan Lian.

32 Ali Muhtarom, "Implementasi Manajemen Sumber Daya Manusia Dalam Peningkatan Profesionalitas Dosen Perguruan Tinggi Agama Islam Provinsi Banten,” Tarbawi, 1.2 (2015), 117-30.

33 Aidah Sari, "Implementasi Pendidikan Karakter Di Sekolah Melalui Kegiatan Pembiasaan Dan Keteladanan,” Tarbawi: Jurnal Keilmuan Manajemen Pendidikan, 3.02 (2017), 249 
personalitas, sifat, tabiat, tempramen, watak" ${ }^{34}$. Oleh sebab itu, pendidikan karakter itu sendiri sudah menjadi bagian integral pendidikan nasional di Indonesia ${ }^{35}$. Pendidikan karakter menurut Gunawan adalah pendidikan untuk membentuk kepribadian seseorang melalui pendidikan budi pekerti, yang hasilnya terlihat dalam tindakan nyata seseorang, yaitu tingkah laku baik, jujur bertanggungjawab, menghormati hak orang lain, kerja keras ${ }^{36}$.

Kepala sekolah sebagai pemimpin puncak di sekolah, memegang peran kunci mewujudkan pendidikan karakter. Oleh karena itu, kepala sekolah sebagai pemimpin di sekolah melakukan Langkah-langkah strategis dalam mengembangkan pendidikan karakter. Selain kepala sekolah guru juga penting dalam mengembangkan pendidikan karakter di sekolah. Guru memiliki kemampuan dalam menyampaikan materi dan guru tidak menjaga jarak dengan peserta didik. Kedekatan guru dengan peserta didik memberi dampak positif dalam pembelajaran. Dukungan guru dalam pendidikan karakter yaitu menjadi contoh yang baik bagi peserta didik mulai dari penanaman karakter relegius, disiplin, maupun motivasi berprestasi ${ }^{37}$. Dengan hal ini, dalam meningkatkan profesionalisme guru telah menunjukkan bahwa profesional guru dapat mengembangkan karakter peserta didik karena guru profesional merupakan guru yang berkualitas, berkompeten, dan guru yang dikehendaki untuk mendatangkan prestasi belajar serta mampu mempengaruhi proses pembelajar.

\section{Peran kepala Sekolah Dalam Meningkatkan Profesional Guru di SMK Cendekia}

Peran kepala sekolah dalam meningkatkan profesionalisme guru di SMK Cendekia Madiun dengan melakukan pemberdayaan kepada guru yang di wujudkan dalam pemberian motivasi, arahan untuk selalu bergerak mengikuti perkembangan dan tuntutan zaman, memberi koordinasi kepada guru, memanfaatkan segala potensi yang dimiliki guru dalam melaksanakan kegiatan pendidikan, pencatatan berbagai kinerja guru dalam melaksanakan tugasnya dan mengadakan program peningkatan profesionalisme guru, dilakukan secara bertahap dan berkesinambungan. Hal ini menunjukkan bahwa peran kepala sekolah dalam melaksanakan pengembangan profesionalisme guru di SMK Cendekia Madiun selalu terlibat secara langsung guna meningkatkan kualitas guru yang dimiliki.

Sebagai manajer, kepala sekolah harus dapat merencanakan suatu tujuan guna mencapai tujuan yang diinginkan secara efektif dan efisien. Kepala sekolah dalam meningkatkan profesionalisme guru di SMK Cendekia dilakukan dengan cara, yang pertama kepala sekolah membuat perencanaan dengan mengacu pada prinsip dan tujuan dari kementrian pendidikan, mengadakan evaluasi diri pada guru dan penilaian kinerja guru sebagai dasar perencanaan. Selanjutnya, Kepala sekolah dengan para guru mengadakan analisis kebutuhan dengan memperhatikan visi, misi dan tujuan sekolah. Perencanaan profesionalisme guru direncanakan dan ditentukan dalam bentuk rapat bersama para guru, wakil kepala sekolah dan seluruh tenaga kependidikan. Dengan demikian menunjukkan bahwa kepala sekolah sebagai manajer di SMK Cendekia Madiun selalu menggunakan fungsi manajemen yang pertama guna meningkatkan profesionalisme guru dengan menerapkan kepemimpinan demokratis untuk mencapai tujuan yang diinginkan secara efektif dan efisien.

Kepala sekolah sebagai manajer selain merencanakan juga ada pengawasan dan evaluasi guna menilai kinerja guru dalam proses pembelajaran. Kepala sekolah SMK Cendekia Madiun sebelum mengadakan kegiatan dalam menunjang profesionalisme guru, melakukan kegiatan supervisi setiap semester untuk mengawasi perkembangan guru dan dua tahun sekali

${ }^{34}$ Rusmaini, "Manajemen Pendidikan Karakter di Lembaga Pendidikan Islam," El-Idare: Jurnal Manajemen Pendidikan Islam, 3.1 (2017), 132-47.

${ }^{35}$ Hendro Widodo \& Etyk Nurhayati.

${ }^{36}$ dan Muzakkir Mukri Pahmi , Muh. Ilyas Ismail, "Internalisasi Pembentukan Karakter dalam Proses Pembelajaran pada SMP Negeri 37 Bulukumba," of Islamic Education Management, 5.2 (2019), 25$37<$ http://jurnal.radenfatah.ac.id/index.php/El-idare/article/view/4024>.

${ }^{37}$ Hendro Widodo \& Etyk Nurhayati. 
memberi nilai atas kinerja guru. Evaluasi dilakukan dengan menggunakan data penilaian kinerja guru dari hasil pengawasan, dan melakukan evaluasi setelah pelatihan dengan melihat keterangan guru telah melaksanakan kegiatan-keatan peningkatan profesionalisme, berupa diklat, seminar, workshop yang telah di ikuti, yang dijadikan acuan perencanaan peningkatan profesionalisme guru yang akan datang. Hal ini menunjukkan bahwa dalam kepemimpinannya kepala sekolah SMK Cendekia Madiun juga menjalankan fungsi manajemen controling yaitu dengan selalu mengawasi dan menilai guru guna meningkatkan proses pembelajaran di sekolah.

\section{Pelaksanaan meningkatkan Profesional Guru Untuk Mengembangkan karakteristik Peserta didik di SMK Cendekia.}

Peningkatan professional guru merupakan salah satu kunci untuk mencapai kesuksesan lembaga pendidikan. Tujuan meningkatkan profesionalisme guru di SMK Cendekia Madiun yaitu untuk mencapai standar kompetensi guru yang ditetapkan dalam peraturan perundangan yang berlaku, guru dapat menguasai pembelajaran dengan baik, penguasaaan penerapan kurikulum K13 pada guru dan memutakhirkan kompetensi guru. Dengan ini menunjukkan bahwa SMK Cendekia Madiun selalu ingin meningkatkan kualitas guru sesuai perundang-undangan yang berlaku.

Kegiatan profesionalisme guru merupakan usaha dilakukan guna meningkatkan kemampuan yang dimiliki guru dalam pembelajaran. Kepala sekolah dibantu para guru dalam meningkatan profesionalisme mengadakan IHT (in House Training) pada awal tahun pembelajaran, Mengadakan kegiatan KKG (Kelompok Kerja Guru) atau MGMP (Musyawarah Guru Mata Pelajaran) untuk berbagi pengalaman dalam memecahkan masalah-masalah yang dihadapi secara bersamaan dan mengadakan kegiatan keluar sekolah berupa pelatihan yaitu diklat, seminar dan workshop. Hal ini menunjukkan bahwa setiap tahunnya di SMK Cendekia selalu ada kegiatan guna meningkatkan kemampuan yang dimiliki guru di sekolah dan kegiatan keluar bagi guru yang perlu mengikuti pelatihan.

Profesionalisme guru di SMK Cendekia Madiun berdampak pada meningkatnya pelayanan pendidikan, terutama dalam proses pembelajaran yang dapat memberikan peningkatan ketrampilan guru dalam mengajar dengan membuat para siswa selalu aktif dalam mengikuti pembelajaran, guru termotivasi semangat dalam mengajar dan meningkatkan kedisiplinan para guru yang dapat menjadi contoh tauladan kepada peserta didik. Hal ini menunjukkan bahwa dalam meningkatkan profesionalisme guru di SMK Cendekia Madiun berdampak meningkatnya kualitas guru yang dapat mengembangkan karakter pada peserta didik. Oleh sebab itu, di SMK Cendekia Madiun, adanya upaya kepala sekolah dalam membentuk karakter peserta didik melalui pengarahkan guru untuk memberi contoh atau tauladan yang baik kepada siswa, mengadakan kegiatan pengembangan karakter peserta didik setahun sekali yang di ikuti seluruh guru dan peserta didik SMK Cendekia Madiun dan memberikan bimbingan, arahan. serta mengadakan kegiatan ekstra kurikuler, mengadakan kegiatan keagamaan, menciptakan aktivitas baru dengan mengadakan cinta alam disekolah berupa penanaman sayur-sayuran bersama, dan pemeliharaan lele yang dibagi setiap kelas dengan pengarahan guru, dan pembiasaan pengembangan budaya sekolah.

Dalam proses pengembangannya di SMK Cendekia Madiun, guru di tuntut untuk menanamkan karakter peserta didik yang jujur, disiplin, mandiri, kreatif, cinta tanah air, sikap demokratis, kerja keras, gemar membaca, perduli terhdap lingkungan, perduli sosial, religius, rasa tanggung jawab, dan terutama sesuai visi dan misi sekolahan yang dapat mengembangkan peserta didik yang terampil, kompetitif, beriman dan bertakwa kepada Tuhan YME. Dengan ini menunjukkan bahwa SMK Cendekia Madiun berprinsip untuk selalu menciptakan peserta didik yang memiliki nilai-nilai karater.

Adapun faktor penghambat dalam pelaksaaannya di SMK Cendekia Madiun adalah terbatasnya waktu dan jam pelajaran, sarana dan prasarana yang belum memadai, lingkungan masyarakat, kurangnya kesadaran, peserta didik untuk mengetahui akan pentingnya 
pendidikan karakter dan masih rendahnya kualitas atau kemampuan secara akademik peserta didik. Adapun faktor pendukung dengan adanya kesadaran peserta didik yang tumbuh dari diri sendiri untuk selalu melakukan perbuatan yang terpuji, guru selalu mendorong siswa membentuk karakter yang berprestasi, berahklak, dan beriman, adanya motivasi maupun dukungan dari orang tua dan dukungan positif dari lingkungan.

\section{Kesimpulan}

Peran kepala sekolah sebagai manajer dalam meningkatkan profesionalisme guru sangat penting dalam mencapai tujuan pendidikan yakni melalui pemberdayaan guru, pemberian motivasi, arahan, koordinasi, dan memanfaatkan potensi yang dimiliki guru dalam pendidikan. Kepala sekolah merencanakan mengacu prinsip dan tujuan kementrian pendidikan dengan mengadakan evaluasi diri pada guru dan analisis kebutuhan pada visi, misi dan tujuan sekolah. Melakukan kegiatan supervisi setiap semester dan evaluasi hasil kegiatankeatan peningkatan profesionalisme guru. Kegiatan profesionalisme merupakan usaha meningkatkan kemampuan guru dengan mengadakan IHT (in House Training), kegiatan KKG (Kelompok Kerja Guru) atau MGMP (Musyawarah Guru Mata Pelajaran) dan mengadakan pelatihan di luar sekolah. Dalam membentuk karakter, mengarahkan guru untuk memberi contoh baik, memberikan bimbingan, arahan, mengadakan kegiatan pengembangan karakter, ekstra kurikuler, dan keagamaan. Selain itu, menciptakan aktivitas baru berupa menanam sayur dan pemeliharaan lele yang dibagi setiap kelas.

Studi ini terbatas pada perspektif peserta didik mengintegrasikan pada peran kepala sekolah dan profesionalisme guru dalam pengembangan karakter pada peserta didik di sekolah. Mengintegrasikan perspektif kepala sekolah dan guru bersama perspektif peserta didik maupun wali murit memungkinkan memperoleh pemahaman yang komprehensif. Sejalan dengan ini diperlukannya penelitian lebih lanjut yang melibatkan dua perspektif dengan pengalaman yang dialami dalam penyelenggaraan pendidikan di sekolah. Dengan demikian, pemecahan masalah yang komperhensif tersebut memungkinkanya dapat ditemukan. 


\section{Daftar Pustaka}

Baharuddin dan Umiarso. (2012). Kepemimpinan Pendidikan Islam: Antara Teori dan Praktek. Jogjakarta: Ar-Ruzz Media.

Charis F., Muhammad. \& Ammar A, Muhammad dkk. (2020). Kategori Kepemimpinan dalam Islam. Jurnal Edukasi Nonformal, o1 (02).

Dalyono, Bambang dan Lestariningsih, Enny Dwi. (2017). Implementasi Pengantar Pendidikan karakter di Sekolah. Jurnal Bangun Rekaprima. 03 (02).

Departemen Agama RI. (2003) Pondok Pesantren dan Madrasah Diniyah: Pertumbuhan dan Perkembanganya. Jakarta: Direktorat Jenderal Kelembagaan Agama Islam.

Edison, Emron. Yohny Anwar \& Imas Komariyah. (2016). Manajemen Sumber Daya Manusia Strategi dan Perubahan dalam Rangka Meningkatkan Kinerja Pegawai dan Organisasi. Bandung: ALFABETA.

Hariyadi, Ahmad. (2020). Kepemimpinan Karismatik Kiai Dalam Membangun Budaya Organisasi Pesantren. Jurnal Equity in Education Journal (EEJ). 02 (o2).

Haryanto, Sugeng. (2012). Persepsi Santri Terhadap Perilaku Kepemimpinan Kiai di Pondok Pesantren. Studi Interaksionisme Simbolik di Pondok Pesantren Sidogiri-Pasuruan. Jakarta: Kementerian Agama RI.

Hasanah, Durrotun. (2017). Manaqib Syeikh Abdul Qadir Sebagai Media Suluk. Jurnal Putih. O2(01).

Inaku, Saifulhaq. \& Nur Iman, Muhammad. (2020). Pendidikan Karakter Berbasis Akhlak. Journal Irfani. 16 (o1).

Mardiyah. (2013) Kepemimoinan Kyai dalam Memelihara Budaya Organisasi. Yogyakarta: Aditya Media Publising.

Minhajjil Qowim, Ahmad Nailu. Fathurrahman Alfa, dkk. (2020). Pembentukan Karakter Cinta Rasul Pada Pemuda Jamaah Majelis Ta'lim Wal Maulid Arridwan Malang. Jurnal VICRATINA: Pendidikan Islam. 05(02).

Noor, Muslichan. (2018). Gaya Kepemimpinan Kyai. Jurnal Kependidikan. 17(o1).

Rosidatun. (2018) Model Implementasi Pendidikan Karakter. Gresik: Caremedia Communication.

Saifullah Al-Azis, Moh. (2020). Manaqib Kisah Kehidupan Syekh Abdul Qodir Al-Jailani, Terjemah. Surabaya: Terbit Terang.

Salahudin, Marwan. (2016). Amalan Thariqat Qadariyah Wa Naqsabandiyah Sebagai Proses Pendidikan Jiwa di Masjid Babul Muttaqin Desa Kradenan Jetis Ponorogo. Jurnal Akhlaq Dan Tasawuf. 02(o1). 
Sholihah, Maratus \& Muslih. (2019). Gaya Kepemimpinan Karismatik Kh. Muhammad Dawam Saleh Dalam Manajemen Pondok Pesantren Al-Islah Sendangagung Paciran Lamongan”. Jurnal MUDIR Manajemen Pendidikan. o1(02).

Sugiyono. (2017) Metode Penelitian Pendidikan (Pendidikan Kuantitatif, Kualitatif, dan RED). Bandung: Alfabeta.

Sulistiyorini1, Defi \& Nurfalah, Yasin. (2019). Pembentukan Karakter Religius Siswa Melalui Kegiatan Dewan Jamaah Mushola (DJM) Di SMK PGRI 2 Kota Kediri. Indonesian Journal of Islamic Education Studies (IJIES). $02(\mathrm{o1})$.

Sukamto. (1999). Kepemimpinan Kiai Dalam Pesantren. Jakarta: Pustaka LP3ES Indonesia.

Sutianah, Elis. Widodo Sunaryo \& Adie E. Yusuf. (2018). Hubungan Antara Gaya Kepemimpinan Karismatik Kepala Sekolah Dan Kepribadian Dengan Keinovatifan Guru. Jurnal Manajemen Pendidikan. o6(o2).

Syafe'I, Imam. (2017). Pondok Pesantren Lembaga Pendidikan Pembentukan Karakter. Journal Pendidikan Islam. o8(o1).

Widodo, Hendro \& etyk nurhayati. (2020). Manajemen pendidikan sekolah, madrasah, dan pesantren. Bandung: PT Remaja Rosrdakarya.

Yahya, Slamet. (2020). Tradisi Manaqib Syekh Abdul Qodir Al-Jailani Al-Jailani Di Mushalla Raudlatut Thalibin Kembaran Kebumen. Jurnal IDBA Kajian Islam dan Budaya.18(1). 